Revista de Metalurgia 52(3)

July-September 2016, e072

ISSN-L: 0034-8570

doi: http://dx.doi.org/10.3989/revmetalm.072

\title{
An experimental study on fracture toughness of resistance spot welded galvanized and ungalvanized DP 450 steel sheets used in automotive body
}

\author{
Ibrahim Sevim ${ }^{\bowtie}$ \\ Mersin University, Engineering Faculty, Department of Mechanical Engineering, 33343 Yenişehir, Mersin, Turkey \\ Corresponding author: isevim@mersin.edu.tr
}

Submitted: 4 November 2015; Accepted: 8 May 2016; Available On-line: 14 October 2016

\begin{abstract}
The purpose of this study is to determine fracture toughness of Resistance Spot Welded (RSW) Dual Phase (DP) steels. RSW of galvanized and ungalvanized DP 450 steel sheets was carried out on spot welding machine. Fracture toughness of RSW joints of galvanized and ungalvanized DP 450 steel sheets was calculated from tensile-shear tests. New empirical equations were developed using Least Squares Method (LSM) between energy release rate, fracture toughness and critical crack size depending on the relationship between hardness and fracture toughness values. Results indicated that fracture toughness of joints welded by using RSW increased exponentially while the hardness decreased. In addition, fracture toughness and energy release rate of RSW galvanized DP 450 steel sheets were lower compared to RSW ungalvanized DP 450 steel sheets which had approximately the same hardness.
\end{abstract}

KEYWORDS: DP steels; Fatigue; Fracture Toughness; Resistance Spot Welding (RSW)

Citation / Cómo citar este artículo: Sevim, I. (2016) "An experimental study on fracture toughness of resistance spot welded galvanized and ungalvanized DP 450 steel sheets used in automotive body". Rev. Metal. 52 (3):e072. doi: http:// dx.doi.org/10.3989/revmetalm.072.

RESUMEN: Estudio experimental sobre la resistencia a la fractura de los aceros de resistencia soldada por puntos DP 450, láminas de acero galvanizado y sin galvanizar utilizados en la estructura del automóvil. El objetivo de este estudio es determinar la tenacidad de fractura de los aceros dual (DP) soldados por puntos de resistencia (RSW). En la máquina de soldadura por puntos se realizó la soldadura de láminas de acero DP 450 galvanizado y sin galvanizar. A partir de los ensayos de tracción-cizallamiento, se calculó la tenacidad a la fractura de las uniones del acero DP 450 galvanizado y sin galvanizar. Aplicando el método de mínimos cuadrados (LSM) se desarrollaron nuevas ecuaciones empíricas entre el porcentaje de energía liberada, la tenacidad de fractura y el tamaño de grieta crítica en función de la relación entre los valores de tenacidad de fractura y de dureza. Los resultados indicaron que la tenacidad de fractura de las uniones soldadas por RSW aumentó exponencialmente, mientras que la dureza disminuyó. Además, el porcentaje de energía liberada de las láminas de acero DP 450 galvanizadas y soldadas fueron menores que en el caso de las láminas sin galvanizar a valores iguales de dureza.

PALABRAS CLAVE: Aceros dual (DP); Fatiga; Resistencia soldada por puntos (RSW); Tenacidad a la fractura

Copyright: (C) 2016 CSIC. This is an open-access article distributed under the terms of the Creative Commons Attribution License (CC-by) Spain 3.0. 


\section{INTRODUCTION}

RSW is a welding method used to join metal sheets up to $5 \mathrm{~mm}$ thickness (Sevim, 2005; Kocabekir et al., 2008). It is the most important welding technique in the production of automotive and other industrial applications (Aslanlar, 2006; Sevim, 2006; Eisazadeh et al., 2010). In automotive industry, Dual Phase (DP) steels are commonly used in automotive body due to vehicle's light weight in providing fuel economy, high strength, good corrosion resistance, and well damping capability (Hayat and Sevim, 2012).

DP steels used in automotive body are welded by RSW (Aslanlar et al., 2008). Approximately 3000 and 4000 RSW processes are used in the manufacturing of each automobile (Sevim et al., 2013). Service life of welded joint depends on the quality of welding (Hayat and Sevim, 2012). These types of joints are forced under static and dynamic (unstable) loads. The performance of welded joints under dynamic loading, less than the static load is. (Pan and Sheppard, 2002). In dynamic loads, a crack is formed in the stress under yield strength of material (Chan, 2010). This crack begins from a fault or discontinuity within the material, progressively proceeds and results in fatigue damage (Dowell and Dunne, 2010). Fatigue damage causes a natural notch effect in RSW zones and carries fewer loads compared to base metal (Sun et al., 2007). Thus, RSW zones are quite critical in respect of fatigue damage (Kang et al., 2000). Stress intensity on the edge of a sharp crack is identified with stress intensity factor (Vural and Akkus, 2004; Vural et al., 2006).

Approaches of fracture mechanics are commonly used in the calculation of stress intensity factor of RSW joints under shear-tension stress loads. The main purpose of fracture mechanics is to determine stress intensity factor. Fracture of a material is expressed with one of three different modes, as seen on Fig. 1 (Broek, 1976; Lawn, 1993). These are opening mode $K_{I}$, shearing mode $K_{I I}$, and tearing mode $K_{I I I}$.

The equation proposed by Pook is the most common one which is used in the calculation of fracture toughness of RSW (Pook, 1975). In this study, Mode II recommended by Pook was used in the

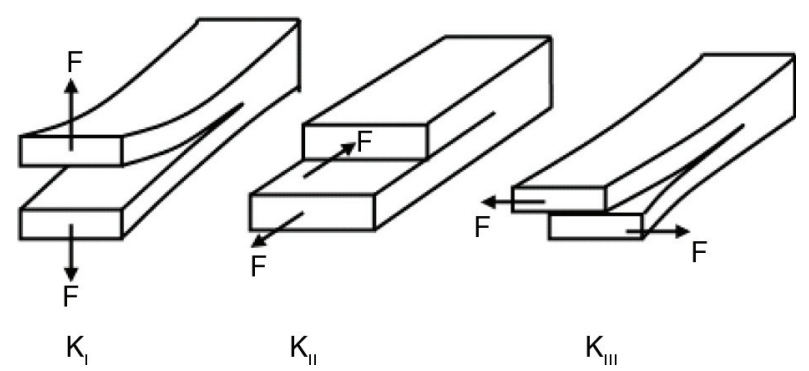

FIGURE 1. Basic fracture modes: KI, opening mode; KII, shearing mode; KIII, tearing mode (Lawn, 1993; Broek, 1976). calculation of fracture toughness of RSW joints. Fracture toughness of RSW joints for Mode II by using test results of shearing-tension loads was calculated from the following Eq. (1):

$$
K_{I I}=\tau\left(\pi \frac{D}{2}\right)^{1 / 2}\left[0.5+0.287\left(\frac{D}{S}\right)\right]^{0.710}
$$

where; $\tau$ is the shearing stress, $\mathrm{D}$ is welding diameter and $\mathrm{S}$ is thickness of welded sheet.

According to Mode II, energy release rate for RSW joints was calculated from Eq. (2) (Broek, 1976) as.

$$
G_{I I}=\frac{K_{I I}^{2}\left(1-v^{2}\right)}{E}
$$

where; $v$ is Poisson rate and $\mathrm{E}$ is Young module.

Altough numerous studies on mechanical properties of RSW joints are available in the literature, there is a limited number of studies regarding fracture toughness of RSW joints.

In this study, new empirical equations were developed using LSM between release rate of strain energy, fracture toughness and critical crack size depending on the relationship between hardness and fracture toughness values. Galvanized and ungalvanized DP 450 steel sheets were used in experiments to investigate fracture toughness of joints welded by RSW.

The paper is organized as follows: In the next section, the details of the proposed study are explained. In the third section, empirical relations were found by using LSM between the fracture toughness and the Vickers hardness of RSW joints. In the fourth section, empirical relations were defined by using LSM between calculated critical crack size and fracture toughness of RSW galvanized and ungalvanized DP 450 steel sheets. In the fifth section, the fracture toughness modes and energy release rate were studied and the crack initiation and structure occurred in welding zone were discussed. Finally, conclusions are presented the last section.

\section{EXPERIMENTAL STUDIES}

In this section, galvanized and ungalvanized commercial DP 450 steel sheets in $1.0 \mathrm{~mm}$ thickness were used. Coating thickness of galvanized DP 450 steel sheet used in experiments was $23 \mu \mathrm{m}$. Chemical compound of the material used in the experiment is given in Table 1.

Test samples were prepared from galvanized DP 450 steel sheets in the dimensions of $100 \times 30 \mathrm{~mm}$. Galvanized samples were dipped in hydrochloric acid $(\mathrm{HCl})$ under laboratory conditions in the zone of $30 \times 30 \mathrm{~mm}$, as illustrated in Fig. 2, and their galvanize layer removed from the surface of the samples. 
TABLE 1. Chemical compounds of the material used in the experiment (wt.\%).

\begin{tabular}{lcccccccccc}
\hline Material & $\mathbf{C}$ & $\mathbf{S i}$ & $\mathbf{M n}$ & $\mathbf{C r}$ & $\mathbf{N i}$ & $\mathbf{N b}$ & $\mathbf{T i}$ & $\mathbf{V}$ & $\mathbf{M o}$ & $\mathbf{F e}$ \\
\hline DP450 & 0.054 & 0.129 & 1.32 & 0.51 & 0.02 & 0.0043 & 0.001 & 0.004 & 0.0029 & Bal. \\
\hline
\end{tabular}

(a)

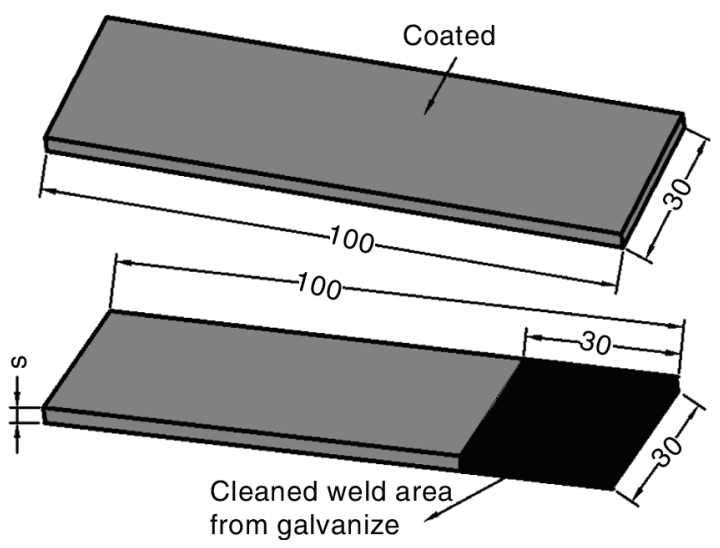

(b)

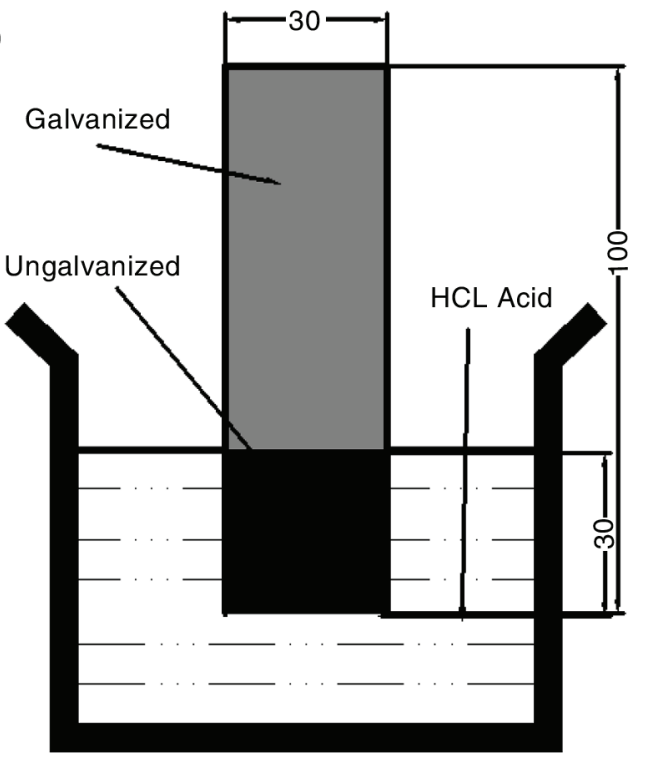

FIGURE 2. (a) dimensions of welded samples and (b) pre-joining removal of galvanized coating.

Samples were prepared according to DIN 17440 standards for RSW as depicted in Fig. 3. Before starting welding, surfaces of samples were cleaned with alcohol. Electrodes used in RSW process are made of copper alloy; and tapered and water cooled electrodes with a diameter of $8 \mathrm{~mm}$ contact surface. Welding variables were welding current, welding time, material composition, and coating status. Welding process was carried out with 10-20-30-40 cycle ( 1 cycle $=0.02$ seconds) welding time and 3-5-7-9 kA of welding current. RSW procedure was carried out in the form of Galvanized+ Galvanized and Ungalvanized+ Ungalvanized DP 450 combinations.

Fracture toughness of RSW joints and data obtained from shear tension tests were used and calculated from Eq. (1). Figure 4 shows dimensions of shearing test sample produced by processing the RSW joints.

As seen in Fig. 5 (a-b), a special tension shearing test device was designed and produced for implementing shearing test of RSW joints. As seen in Fig. 5c, RSW pieces were tested in tension-shearing mode. Tension-shearing load was taken as maximum fracture load.

Fracture load of welded parts was determined by data obtained from tension shearing test. Nugget diameters of RSW joints were measured with optical microscope from the surfaces of fractured. Nugget diameters of RSW joints were determined by performing three measurements on from each sample and calculating the arithmetic means of these measurements. Fracture toughness and energy release rate of RSW joints were calculated by using equations (1) and (2).

Nugget and heat affected zones of RSW welded pieces were grinded by using $80-1200$ grit abrasive paper and polished with $0.3 \mu \mathrm{m}$ diamond paste and etched. Hardness measurements of the surface were performed.under $1.96 \mathrm{~N}\left(\mathrm{HV}_{0.2}\right)$ load.

\section{RESULTS}

Fracture toughness $\left(\mathrm{K}_{\text {IIC }}\right)$ of RSW galvanized and ungalvanized DP 450 sheets and the variation with Vickers hardness measured from welding interface is shown in Fig. 6. As seen in Fig. 6, fracture toughness of ungalvanized DP 450 joints was higher than the galvanized ones. Additionally, Table 2 illustrates nugget images of ungalvanized and galvanized DP 450 steel sheets welded by using RSW. As seen from the images, even though both materials were welded in the same welding conditions, ungalvanized joints formed bigger welding diameters and welding depths. When compated to galvanized ones.

Figures 7 and 8 illustrates variations in energy release rate $\left(\mathrm{G}_{\text {IIC }}\right)$ and fracture toughness $\left(\mathrm{K}_{\mathrm{IIC}}\right)$ according to the hardness of welding interface. As seen from graphics, while Vickers hardness was increasing, fracture toughness and energy release 


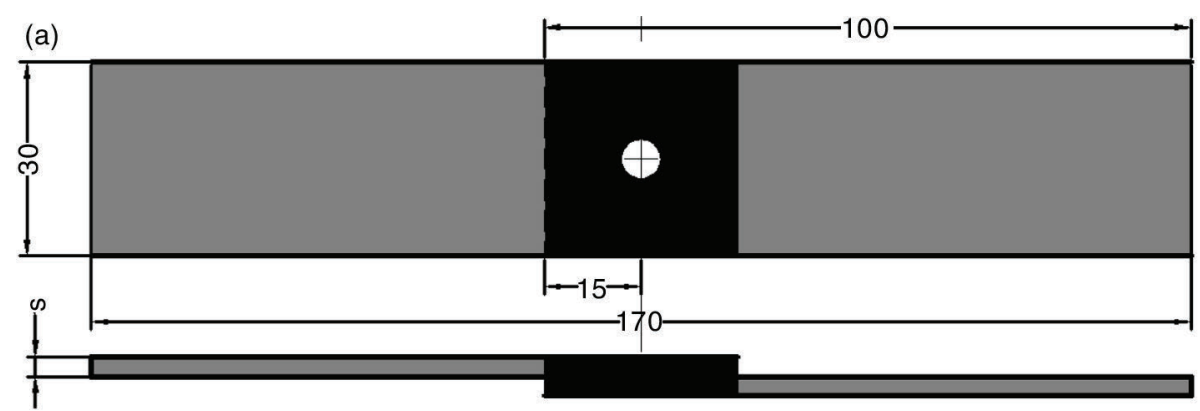

(b)
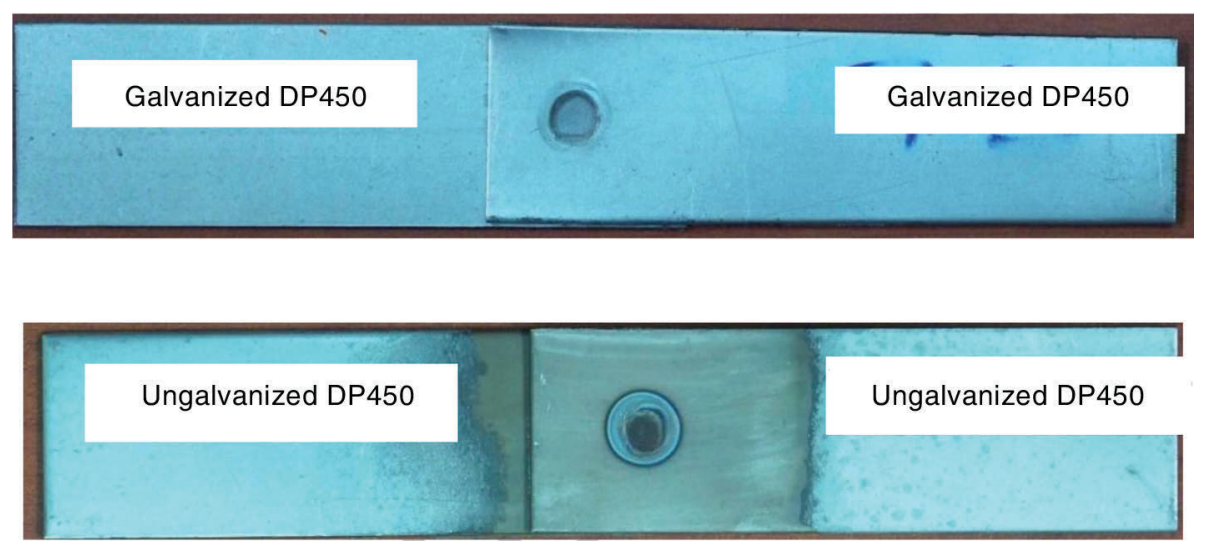

FIGURE 3. (a) RSW samples according to DN17440 and (b)corrosponding images for galvanized and ungalvanized DP450.

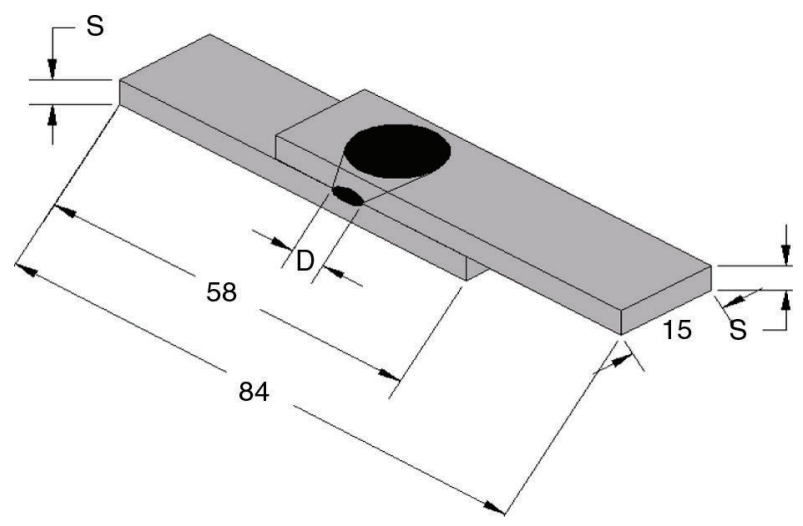

FiguRE 4. Dimensions of tension-shear test sample for apparatus in shearing assembly.

rate for both galvanized and ungalvanized DP 450 were decreased. This decrease is proportional to $H^{-6}$ for fracture toughness and $H^{-10}$ for energy release rate.

In this study, following empirical relations were found between the fracture toughness and the Vickers hardness of RSW joints. Curve fitting was implemented by using LSM for Figs. 6-8.

For galvanized DP450 steels, $\mathrm{K}_{\mathrm{IIC}}$ is given as:

$$
K_{I I C}=6 \times 10^{22} \cdot H^{-6}
$$

For ungalvanized DP450 steels, $\mathrm{K}_{\mathrm{IIC}}$ is given as:

$$
K_{I I C}=10,5 \times 10^{22} \cdot H^{-6}
$$

where, $\mathrm{K}_{\text {IIC }}$ is fracture toughness according to Mode II and $H$ is Vickers hardness of material.

The effect of crack on fracture can be expressed as given below;

$$
K_{I I} \geq K_{I I C}
$$

The following statement for $\mathrm{K}_{\mathrm{II}}$ was used as below (Sevim, 2005; Kulekci et al., 2005; Kulekci et al., 2012) for calculating critical crack size in this study.

$$
K_{I I}=\tau \sqrt{\pi a_{I I C}}
$$

where, $\tau$ is implemented shear stress and $a_{\mathrm{IIC}}$ is critical crack size. Also; Plastic deformation can be stated as the following;

$$
\tau \cong \tau_{\text {yield }}
$$

and

$$
\tau_{\text {yield }}=\frac{\sigma_{\text {yield }}}{2}
$$


(a)

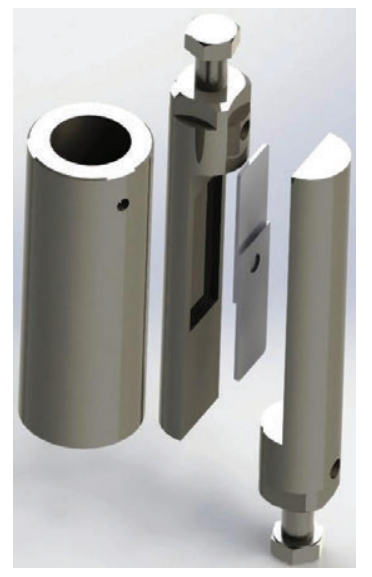

(b)

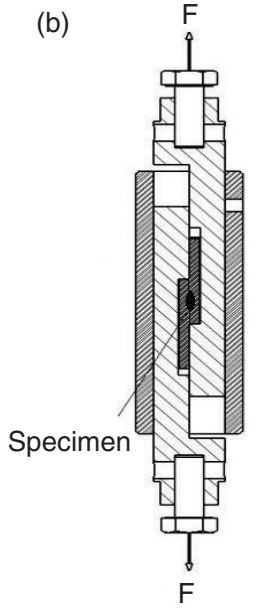

(c)

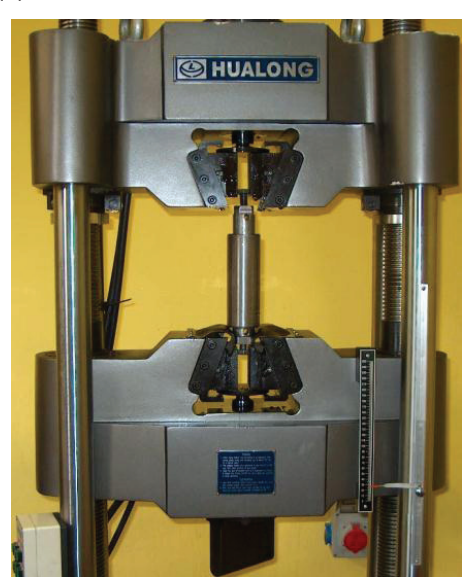

FIGURE 5. (a) shearing mode (KII)- implemented apparatus, (b) cut view of apparatus in shearing assembly and (c) the view of tension test machine.

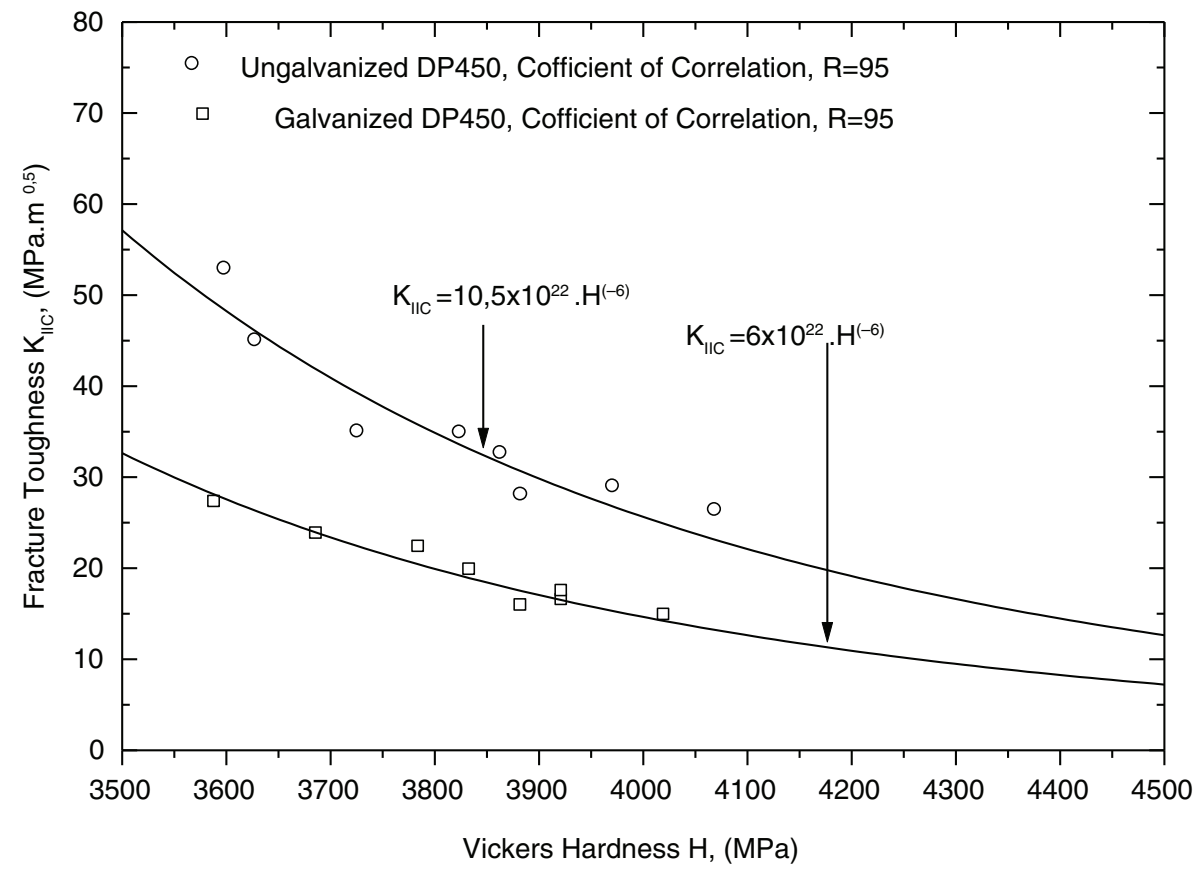

FIGURE 6. Fracture toughness variation with hardness in RSW of both galvanized and ungalvanized DP 450.

Relationship between hardness and yield stress (Gahr Zum, 1987) can be identified as below;

$H \cong 3 \sigma_{\text {yield }}$

Stress intensity factor can be expressed by the following equation, by using Eq. (8):

$$
K_{I I}=\frac{H}{6} \sqrt{\pi \cdot a_{I I C}}
$$

When Eq. (9) is placed in equation ( $3 a$ and b), the following equations are obtained:
$\frac{H}{6} \sqrt{\pi \cdot a_{I I C}} \geq 10,5 \times 10^{22} \cdot H^{-6}$

Fracture toughness 10 (a) equation of galvanized DP 450 steel sheets by using RSW and fracture 
TABLE 2. Nugget images of ungalvanized and galvanized DP 450 steel sheets welded by RSW (Sevim et al., 2013).

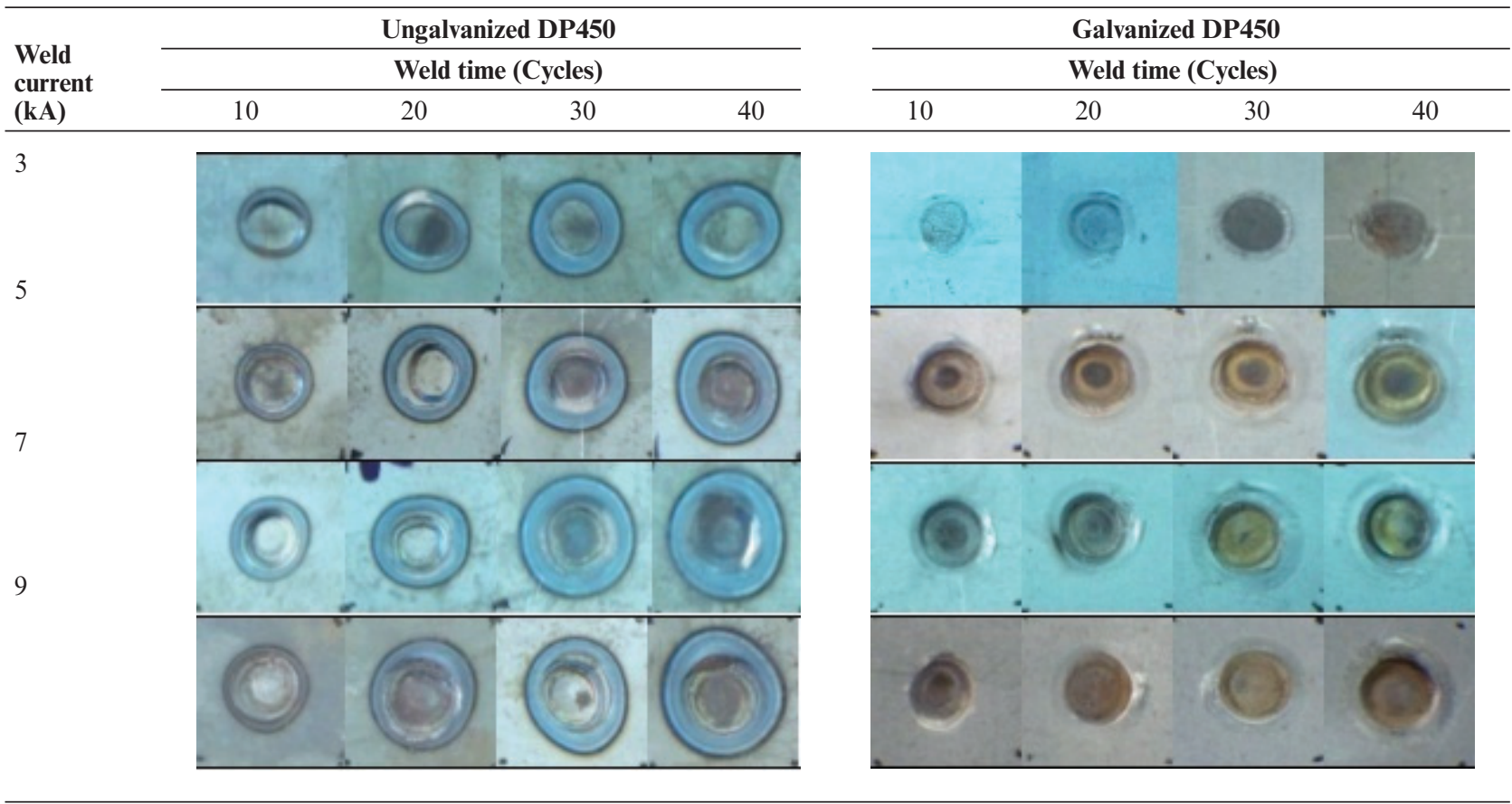

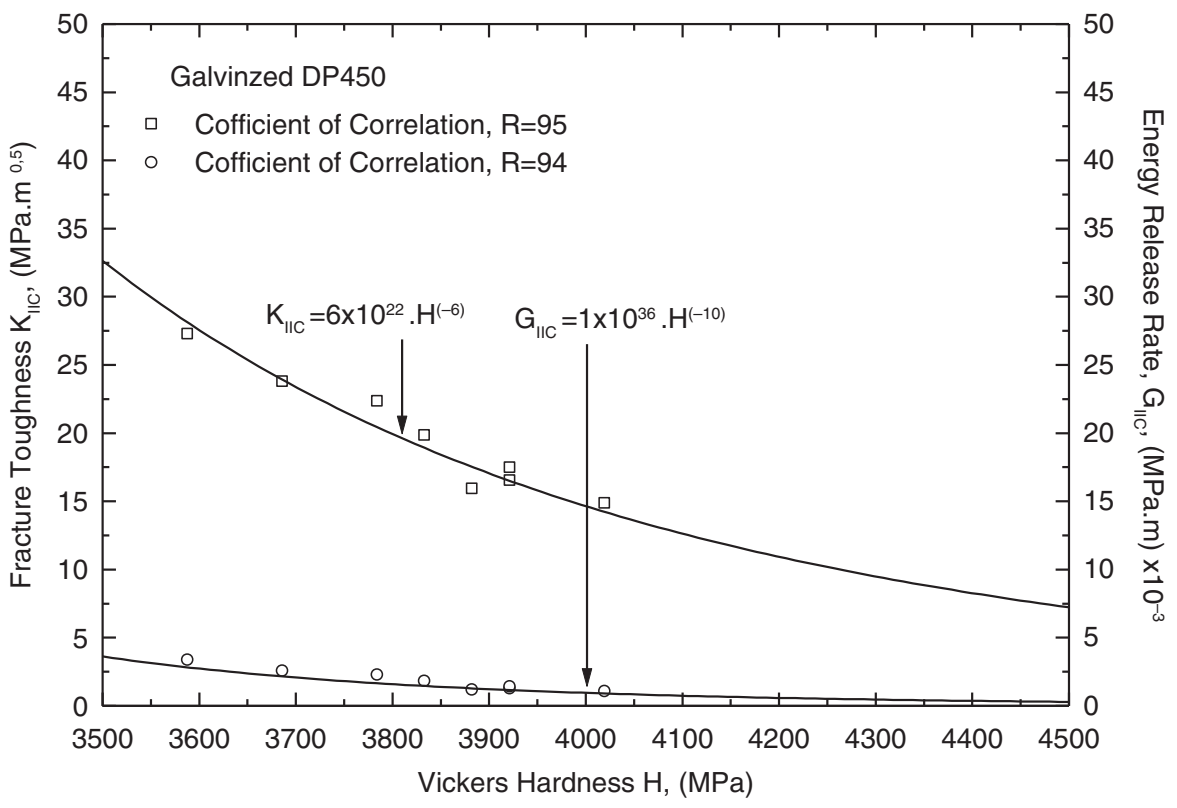

FIGURE 7. Fracture toughness and energy release rate variation with hardness in RSW of galvanized DP 450.

toughness 10 (b) equation of galvanized DP 450 steel sheets welded by using RSW were obtained. When 10 (a) and (b) equations were edited again, critical crack size $a_{I I C}$ can be stated as follows;

$$
a_{I I C} \geq \frac{\pi}{36}\left(\frac{6 \times 10^{22}}{H^{8}}\right)^{2}
$$

$a_{I I C} \geq \frac{\pi}{36}\left(\frac{10,5 \times 10^{22}}{H^{8}}\right)^{2}$

Figures 9 and 10 illustrate the variation in fracture toughness and energy release rate variation according to critical crack sizes calculated 
An experimental study on fracture toughness of resistance spot welded galvanized 7

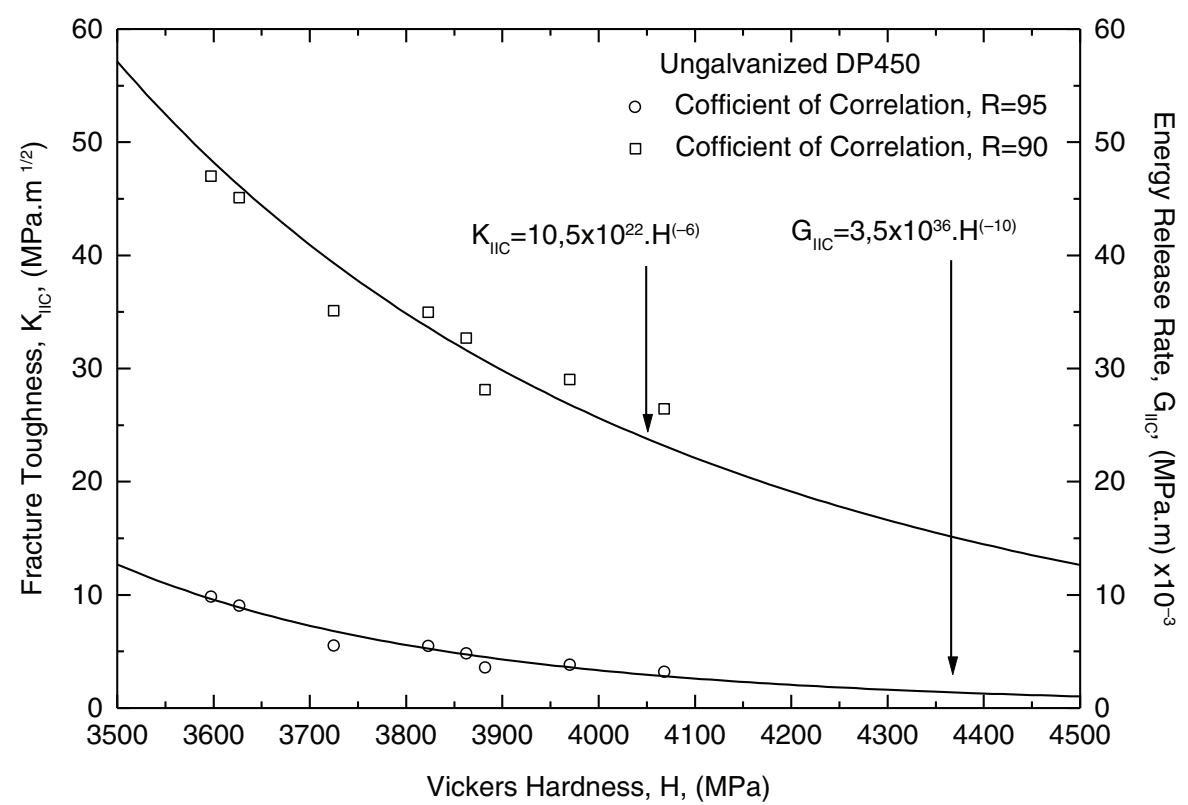

FIGURE 8. Fracture toughness and energy release rate variation with hardness in RSW of ungalvanized DP 450.

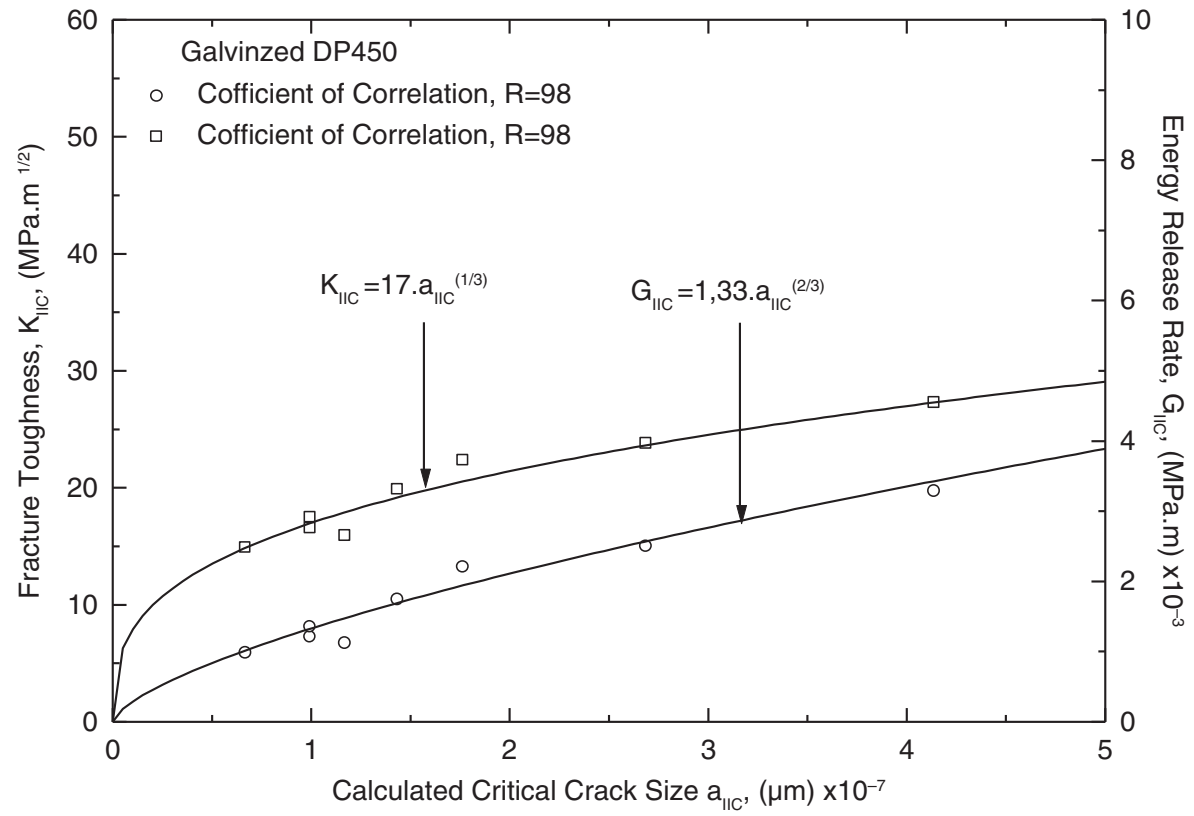

FIGURE 9. Fracture toughness and energy release rate variation with calculated critical crack size in RSW of galvanized DP 450.

by equations 11 (a) and (b). As seen from in Figs. 9 and 10 , calculated critical crack size was very small.

In this study, following empirical relations were defined between calculated critical crack size and fracture toughness of RSW galvanized and ungalvanized DP 450 steel sheets. Curve fitting was implemented by using LSM in Figs. 9 and 10, respectively.

$$
K_{I I C}=17 \cdot a_{I I C}^{1 / 3}
$$

$K_{I I C}=30 \cdot a_{I I C}^{1 / 3}$

As seen from Figs. 9 and 10, the increase in the calculated critical crack size was the (2/3) exponential of energy release rate. 


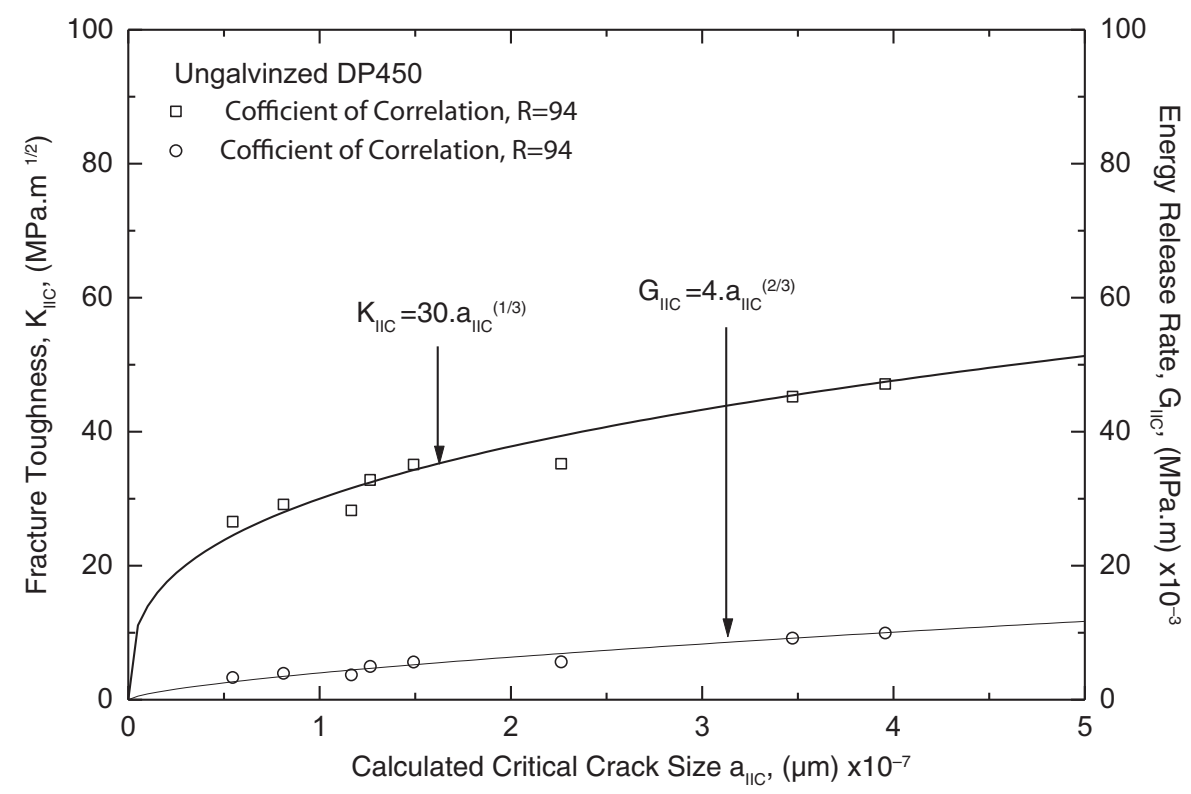

FIGURE 10. Fracture toughness and energy release rate variation with calculated critical crack size in RSW of ungalvanized DP 450.

\section{DISCUSSION}

Figures 6 thru 8 illustrate fracture toughness of RSW joined galvanized and ungalvanized DP 450 steel sheets and the variation of energy release rates based on hardness. As seen from Figs. 6 thru 8, fracture toughness and energy release rate of galvanized DP 450 steel sheets welded by RSW were lower compared to ungalvanized DP 450 steel sheets welded by RSW. Furthermore, Table 2 illustrates nugget image of ungalvanized and galvanized DP 450 steel sheets welded by RSW. As seen from images, even though both of the materials were welded under the same welding conditions, ungalvanized steel sheets welded by RSW formed bigger weld diameters and weld depths. This can be explained with the zinc coating of galvanized DP 450 steel sheets that was $23 \mu \mathrm{m}$. Owing to this zinc coating, galvanized steels do not show high contact resistance compared to ungalvanized steels. Thus, a lower heat is produced on interface of galvanized steels under the same welding conditions. To compensate this, both welding current and welding time are increased about $25 \%$ to $50 \%$ in galvanized steels (Müftüoğlu and Keskinel, 2007). As seen from Figs. 7 and 8, fracture toughness and energy release rates of galvanized and ungalvanized DP 450 steel sheets welded by RSW were decreased exponentially as a function of hardness.

From the Figs. 9 and 10, it was observed that galvanized steel sheets welded with RSW which had approximately the same fracture toughness and energy release rates had lower critical crack size compared to ungalvanized ones. This situation can be explained in the studies of Zhang, Müftüoğlu and Keskinel literature (Müftüoğlu and Keskinel, 2007; Zhang et al., 2008).
As seen from the graphics in Figs. 9 and 10, the calculated critical crack sizes were very small such that they are at the microscopic level. The formation mechanism of this could be explained as follows; nugget area in RSW was a complete cast structure because of melting in weld zone during welding. Based on cooling rate of welding zone and characteristics of material couple, various phase structures could be formed within the material in the weld nugget and heat-affected zone. Furthermore, contraction and cold cracks easily occur based on cooling rate of welding zone (Lee and Kim, 2004; Sevim, 2006; Hayat and Sevim, 2012). Thus, potential critical cracks within weld structure, segregations within welding structure which could initiate the fracture, grain boundaries, micro porosity and capillary cracks are crack start zone (Lee and Kim, 2004). These also help the crack to advance and consequently, results in damage in RSW joints (Lee and Kim, 2004). The fracture of welding as the result of tension-shearing force depends on this structure. It is explained that as, ceramic and metallic alloys increased hardness of plastic, their fracture toughness decreased and the above reasons affected the fracture of material (Gahr Zum, 1987). Variation of critical crack sizes calculated for fracture of the welding increased as exponential function according to fracture toughness and energy release rates for both of the galvanized and ungalvanized DP 450 steel sheets welded by using RSW.

Hardness of martensitic structure occurred in welding zone can be written as follows depending on carbon ratio in alloy (Ma et al., 2008);

$$
H_{M}=884 . C\left(1-C^{2}\right)+294
$$


where; $\mathrm{H}_{\mathrm{M}}$ is hardness of martensitic structure and $\mathrm{C}$ is carbon ratio of alloy.

Hardness on nugget area of welded joint can be estimated as $\mathrm{H}_{\mathrm{M}}=834 \mathrm{MPa}$ from Eq. (13). This value is within hardness range measured on welding zone. This results reveal that the weld nugget completely transformed into martensitic structure.

\section{CONCLUSIONS}

In this article, new empirical equations were developed using LSM between energy release rate, fracture toughness and critical crack size depending on the relationship between hardness and fracture toughness values. The following deducations were drawn based on studies presented in this article:

- Fracture toughness and energy release rates of galvanized DP 450 steel sheets welded by RSW were lower than ungalvanized.

- Ungalvanized steel sheets welded by RSW formed bigger weld diameters and weld depths.

- Both fracture toughness and energy release rates of galvanized and ungalvanized DP 450 steel sheets welded by using RSW decreased exponentially as a function of hardness.

- Variations of calculated critical crack sizes according to fracture toughness and energy release rates of both galvanized and ungalvanized DP 450 steel sheets welded by using RSW increased as exponential function.

- Calculated critical crack sizes were very small within the microscopic sizes.

- It was determined from hardness measurement of weld nugget and calculations that the phase forming in weld nugget completely transformed into martensitic structure.

\section{REFERENCES}

Aslanlar, S. (2006). The effect of nucleus size on mechanical properties in electrical resistance spot welding of sheets used in automotive industry. Mater. Design 27 (2), 125-131, http://dx.doi.org/10.1016/j.matdes.2004.09.025.

Aslanlar, S., Ogur, A., Ozsarac, U., Ilhan, E. (2008). Welding time effect on mechanical properties of automotive sheets in electrical resistance spot welding. Mater. Design 29 (7), 1427-1431. http://dx.doi.org/10.1016/j.matdes.2007.09.004.

Broek, D. (1976). Elementary Engineering Fracture Mechanics, Noordhoff International Publishing, Neyden.

Chan, K.S. (2010). Roles of microstructure in fatigue crack initiation. Int. J. Fatigue 32 (9), 1428-1447. http://dx.doi. org/10.1016/j.ijfatigue.2009.10.005

Dowell, D.L., Dunne, F.P.E. (2010). Microstructure-sensitive computational modeling of fatigue crack formation. Int. J. Fatigue 32 (9), 1521-1542. http://dx.doi.org/10.1016/j. ijfatigue.2010.01.003.

Eisazadeh, H., Hamedi, M., Halvaee, A. (2010). New parametric study of nugget size in resistance spot welding process using finite element method. Mater. Design 31 (1), 149-157. http://dx.doi.org/10.1016/j.matdes.2009.06.042.

Gahr Zum, K.H. (1987). Microstructure and Wear of Material, Elsevier Science Publishers B.V., Amsterdam.

Hayat, F., Sevim, I. (2012). The effect of welding parameters on fracture toughness of resistance spot-welded galvanized DP600 automotive steel sheets. Int. J. $A d v$. Manuf. Tech. 58 (9), 1043-1050. http://dx.doi.org/10.1007/ s00170-011-3428-x.

Kang, H., Barkey, M.E., Lee, Y. (2000). Evaluation of multiaxial spot weld fatigue parameters for proportional loading. Int. J. Fatigue 22 (8), 691-702. http://dx.doi.org/10.1016/ S0142-1123(00)00037-2.

Kocabekir, B., Kaçar, R., Gündüz, S., Hayat, F. (2008). An effect of heat input, weld atmosphere and weld cooling conditions on the resistance spot weldability of 316L austenitic stainless steel. J. Mater. Process. Tech. 195 (1-3), 327-335. http://dx.doi.org/10.1016/j.jmatprotec.2007.05.026.

Kulekci, M.K., Mendi, F., Sevim, I., Baștürk, O. (2005). Fracture toughness of friction stir welded joints of $\mathrm{AlCu} 4 \mathrm{SiMg}$ aluminium alloy. Metalurgija 44 (3), 209-213.

Kulekci, M.K., Sevim, I., Esme, U. (2012). Fracture Toughness of Friction Stir-Welded Lap Joints of Aluminum Alloys. J. Mater. Eng. Perform. 21 (7), 1260-1265. http://dx.doi. org/10.1007/s11665-011-0017-y.

Lawn, B. (1993). Fracture of Brittle Solids, $2^{\text {nd }}$ Edition, Cambridge University Press, Cambridge.

Lee, H., Kim, N., (2004). Fatigue life prediction of multi-spotwelded panel structures using an equivalent stress intensity factor. Int. J. Fatigue 26 (4), 403-412. http://dx.doi. org/10.1016/j.ijfatigue.2003.07.001.

Ma, C., Chen, D.L., Bhole, S.D., Boudreau, G., Lee, A., Biro, E. (2008). Microstructure and fracture characteristics of spotwelded DP600 steel. Mat. Sci. Eng. A-Estruct. 485 (1-2), 334-346. http://dx.doi.org/10.1016/j.msea.2007.08.010.

Müftüoğlu, F., Keskinel, T. (2007) Effect of Coating Thickness on Electrode Life in the Spot Welding of Galvanized Steels. Turkish J. Eng. Env. Sci. 31 (3), 183-187.

Pan, N., Sheppard, S. (2002). Spot welds fatigue life prediction with cyclic strain range. Int. J. Fatigue 24 (5), 519-528. http://dx.doi.org/10.1016/S0142-1123(01)00157-8.

Pook, L.P. (1975). Fracture Mechanics Analysis of the Fatigue Behavior of Spot Welds. Int. J. Fracture 11 (1), 173-176. http://dx.doi.org/10.1007/BF00034726.

Sevim, I. (2005). Fracture Toughness of Spot-Welded Steel Joints. Kovove Mater. 43 (2), 113-125.

Sevim, I. (2006). Effect of hardness to fracture toughness for spot welded steel sheets. Mater. Design 27 (1), 21-30. http:// dx.doi.org/10.1016/j.matdes.2004.09.008.

Sevim, I., Hayat, F., Kulekci, M.K. (2013). Nucleus geometry and mechanical properties of resistance spot welded coateduncoated DP automotive steels. B. Mater. Sci. 36 (6), 1049-1055. http://dx.doi.org/10.1007/s12034-013-0559-8.

Sun, X., Stephens, E.V., Khaleel, M.A. (2007). Fatigue behaviors of self-piercing rivets joining similar and dissimilar sheet metals. Int. J. Fatigue 29 (2), 370-386. http://dx.doi. org/10.1016/j.ijfatigue.2006.02.054.

Vural, M., Akkus, A. (2004). On the resistance spot weldability of galvanized interstitial free steel sheets with austenitic stainless steel sheets. J. Mater. Process. Tech. 153-154, 1-6. http://dx.doi.org/10.1016/j.jmatprotec.2004.04.063.

Vural, M., Akkus, A., Eryurek, B. (2006). Effect of welding nugget diameter on the fatigue strength of the resistance spot welded joints of different steel sheets. J. Mater. Process. Tech. 176 (1-3), 127-132. http://dx.doi.org/10.1016/j. jmatprotec.2006.02.026.

Zhang, X.Q., Chen, G.L., Zhang, Y.S. (2008). Characteristics of electrode wear in resistance spot welding dual-phase steels. Mater. Design 29 (1), 279-283. http://dx.doi.org/10.1016/j. matdes.2006.10.025. 